\title{
Buklet Digital sebagai Pengingat Warga terhadap Protokol Kesehatan Covid-19
}

\author{
Prima Agustina Mariamurti ${ }^{1}$, Tania Intan $^{2}$, Sri Rijati Wardiani ${ }^{3}$ \\ Universitas Padjadjaran ${ }^{1,2,3}$ \\ p.a.mariamurti@unpad.ac.id ${ }^{1}$, tania.intan@unpad.ac.id ${ }^{2}$, sri.rijati@unpad.ac.id ${ }^{3}$
}

\begin{abstract}
People were stunned as the number of Covid-19 victims around the world exploded. Everyone should live with this virus that has not yet found a cure and the number of infected and dead patients is increasing. Every government put health protocols to protect the citizen's well-being. The 3M's behaviour (wearing a mask, maintaining distance, washing hands) will prevent people from being infected with the virus. However, the number of mortality has not decreased. Through community service activities that are integrated with student community service programs, online interviews and surveys are conducted with partners around student residences to find out public awareness of health protocols. People already know and implement this protocol, but the pandemic condition which has been going on for almost a year has made them ignorant and negligent. This situation requires a constant reminder about the Covid-19 virus and its prevention. One option that can be accessed online is through digital booklets, which can be easily opened from any gadget and also be distributed to others. This activity also shows that to get through the pandemic period, everyone must have insight and a willingness to receive relevant knowledge.
\end{abstract}

Keywords: Health protocol; Awareness; Pandemic; Covid-19; Digital booklet.

\begin{abstract}
Abstrak
Pada awalnya, siapa pun terpana ketika terjadi ledakan jumlah korban Covid-19 di seluruh penjuru dunia. Semua orang harus membiasakan diri hidup bersama virus yang belum ditemukan obatnya ini. Jumlah penderita terinfeksi maupun meninggal meningkat. Pemerintah pun berupaya melindungi warganya dengan menetapkan protokol kesehatan. Perilaku 3M (memakai masker, menjaga jarak, mencuci tangan) akan menghindarkan warga dari terinfeksi virus. Namun, jumlah penderita belum menurun. Melalui kegiatan pengabdian kepada masyarakat yang diintegrasikan dengan kuliah kerja mahasiswa, dilakukan wawancara dan survei secara daring terhadap mitra di sekeliling tempat tinggal mahasiswa untuk mengetahui kesadaran warga akan protokol kesehatan. Pada dasarnya, warga telah mengetahui dan menjalankan protokol tersebut, tetapi kondisi pandemi yang telah hampir setahun berlangsung membuat warga abai sehingga memerlukan pengingat tentang virus Covid-19 dan pencegahannya. Salah satu pilihan cara yang dapat diakses secara daring adalah melalui buklet digital, yang mudah diakses dan disebarluaskan warga dari gawainya. Kegiatan ini juga menunjukkan bahwa untuk dapat melalui masa pandemi, setiap orang harus memiliki wawasan dan kesediaan untuk menerima berbagai pengetahuan yang relevan.
\end{abstract}

Kata kunci: Protokol kesehatan; Kesadaran; Pandemi; Covid-19; Buklet digital. 


\section{A. PENDAHULUAN}

Data statistik yang ditampilkan Johns Hopkins University Center for Systems Science and Engineering (JHU CSSE) menunjukkan bahwa warga yang terinfeksi virus Covid-19 di Indonesia mengalami kenaikan sejak penyebaran virus tersebut berubah menjadi pandemi pada tahun 2020 lalu. Berawal dari dilaporkannya 21 kasus pada bulan Maret 2020, jumlah tersebut bertambah dari hari ke hari. Tiga bulan selepas masa Pembatasan Sosial Berskala Besar (PSBB) secara nasional maupun regional yang berawal pada bulan Maret 2020, jumlah kasus semakin bertambah. Di bulan Mei, rata-rata jumlah kasus perminggu sekitar 600-an. Angka ini merambat naik menjadi 1700 -an kasus per-minggu di bulan Juli. Pada akhir Agustus, angka jumlah kasus bertambah menjadi 2000-an kasus bahkan di pertengahan September sempat menyentuh 4.300-an kasus per-minggu.

Di awal November, jumlah rata-rata kasus agak menurun menjadi 3000-an kasus, tetapi menuju akhir tahun 2020, angka tersebut makin menjulang dari 4000-an kasus (akhir November), ke 6000-an kasus (pertengahan Desember), bahkan pada awal Januari 2021 hampir menembus 8000-an kasus, dan pada saat vaksinasi awal di Indonesia dimulai pada tanggal 13 Januari 2021, jumlah kasus masih meningkat ke arah 13.000-an kasus per-minggu, menurut data yang JHU CSSE Covid-19. Tingkat kematian akibat infeksi virus Covid-19 berkisar 200-an jiwa per-hari, meskipun jumlah yang sembuh senantiasa bertambah.

Dilihat dari mikroskop elektron, ukuran diameter SARS-CoV-2 (Covid-19) ini sekitar $60-140$ nanometer (nm). Sebagai perbandingan, pada umumnya semut berukuran 5 milimeter $(\mathrm{mm})$ dan kutu debu berukuran 200 mikrometer $(\mu \mathrm{m})$, menurut Benedette Cuffari (2021) dalam situs News
Medical Lifesciences. Ukuran yang superkecil tersebut membuat virus mudah terbawa dan menyebar di udara melalui percikan dahak penderita. Oleh karenanya, penularan Covid-19 mudah terjadi akibat (1) percikan ludah yang tak sengaja hinggap di sekitar penderita, (2) tangan yang telah menyentuh permukaan yang dihinggapi cipratan ludah penderita Covid-19, menjamah bagian muka, hidung, wajah, dan (3) kontak jarak antara penderita dan orang lain yang terlalu dekat. Siapa pun dapat terpapar virus corona Covid-19.

\begin{tabular}{lrr}
\multicolumn{1}{c}{ Keputusan $\quad \begin{array}{c}\text { Menteri } \\
\text { Republik }\end{array}$ Kesehatan } \\
Indonesia & Nomor \\
HK.01.07/MENKES/382/2020 & $(2020)$
\end{tabular}
menjelaskan tindakan yang harus dilakukan warga agar satu sama lain terlindungi dari paparan virus Covid-19 ketika berada di tempat-tempat umum dan fasilitas umum. Di setiap lokasi umum, pihak pengelola, penjual atau pekerja, dan pengunjung atau tamu perlu menjalankan aturan umum utama yang disingkat menjadi $3 \mathrm{M}$, yaitu 1) menjaga jarak; 2) mencuci tangan; 3) memakai masker. Namun, himbauan penting di masa pandemi ini terlihat belum sepenuhnya dijalankan warga.

Mungkin saja masyarakat mulai lelah karena telah hampir setahun hidup berdampingan bersama virus. Orang-orang menjadi abai terhadap bahaya yang mengintai kesehatan bahkan nyawa mereka. Padahal penyebaran virus hanya bisa ditahan jika semua orang memiliki kesadaran untuk menjaga diri sendiri serta orang-orang yang berada di sekelilingnya. Dengan semakin sedikit yang peduli, akan semakin banyak lagi korban berjatuhan. Vaksinasi yang baru dilakukan pada pertengahan Januari 2021 masih perlu berproses demi mencapai kondisi imunitas komunitas umum sebanyak $70 \%$ itu.

Kegelisahan akan perilaku warga menjadi gagasan dilakukannya pengabdian pada masyarakat bertema "Kesadaran Warga 
terhadap Protokol Kesehatan Covid-19". Bersama dua puluh mahasiswa yang melaksanakan kegiatan Kuliah Kerja Nyata (KKN) virtual, diharapkan akan terkuak permasalahan atau alasan terkait dijalankan atau tidaknya protokol tersebut oleh warga. Warga berarti siapa saja, baik perempuan atau laki-laki, dari beragam latar belakang pendidikan dan pekerjaan, yang dipilih menjadi mitra dan berada di sekitar tempat tinggal mahasiswa KKN.

\section{B. PELAKSANAAN DAN METODE}

Sesuai arahan Direktorat Riset dan Pengabdian Masyarakat Universitas Padjadjaran, pengabdian pada masyarakat (PPM) dosen yang diintegrasikan dengan kegiatan KKN tetap berlangsung dan dilakukan secara virtual selama masa pandemi. Kegiatan PPM-KKN virtual ini dilakukan mulai 11 Januari 2021 sampai 10 Februari 2021 dan ditujukan bagi siapa saja, khususnya mereka yang bersedia dan mampu mengikuti kegiatan penyuluhan. Bersedia artinya memiliki waktu untuk mengikuti kegiatan KKN dan mampu berarti memiliki kuota internet dan berada di tempat dengan sinyal komunikasi yang baik, mengingat seluruh kegiatan dilakukan secara daring. Setiap mahasiswa peserta KKN dipersilakan menentukan dua orang mitra atau objek sasaran. Agar mencapai sasaran yang lebih luas dan beragam, dipilih mitra dengan latar profesi beragam.

Kegiatan dilakukan dalam tiga tahap: a) tahap persiapan; b) tahap pelaksanaan; dan c) tahap evaluasi. Data kualitatif mengenai mitra dan kesadaran terhadap protokol kesehatan Covid-19 dikumpulkan sejak tahap persiapan melalui survei dan diskusi secara daring antara mahasiswa dan calon mitra. Survei awal ini dibuat untuk mengetahui latar belakang mitra dan kesediaan untuk menjadi mitra, serta mengetahui wawasan mereka tentang protokol kesehatan Covid-19. Tahap ini menentukan pemilihan metode dan cara penyampaian materi. Akhirnya digunakan cara penyuluhan serta penyebaran buklet digital.

Materi yang disampaikan adalah mengenai 1) virus Covid-19; 2) cara melindungi diri dari penyebaran virus melalui protokol kesehatan secara benar; 3) realitas dalam masyarakat terkait protokol kesehatan; dan 4) fungsi vaksinasi. Keempat subtopik ini disiapkan oleh mahasiswa kemudian dipresentasikan oleh tiap kelompok mahasiswa pada saat peluncuran buklet digital.

Untuk memantau dan memudahkan kerja sama antara dosen pembimbing lapangan dan para mahasiswa KKN, digunakan sarana aplikasi kolaborasi Trello. Aplikasi ini juga berfungsi seperti logbook bagi mahasiswa, untuk mencatatkan kegiatan masing-masing selama kegiatan $\mathrm{KKN}$ berlangsung.

\section{HASIL DAN PEMBAHASAN}

Buklet adalah salah satu wujud buku. Menurut Baudrillard (1970), filsuf Prancis, buku adalah model teknis. Susunan komunikasi di dalamnya (potongan visual, huruf, kata-kata, halaman, dll) merupakan model yang paling dapat meresap dalam pikiran manusia dalam waktu lama, apa pun simbol, gagasan maupun fantasi yang terkandung dan terwujud di situ. "Les effets de la technologie ne se font pas voir au niveau des opinions et des concepts, mais altèrent les rapports sensibles et les modèles de perception continûment et inconsciemment" - Efek teknologi tidak ada kaitannya dengan tingkatan pemikiran dan konsep, tetapi senantiasa mengubah hubungan yang peka serta pola persepsi 
tanpa disadari (terjemahan bebas). Dalam kaitannya dengan kegiatan PPM, materi apa pun yang akan disampaikan pada warga memerlukan medium yang mudah dijangkau warga di masa serba daring ini. Buklet digital menjadi pilihan karena dapat diakses melalui gawai (HP, tablet). Wujud ini membedakan luaran PPM ini dari PPM sebelumnya dengan tema serupa. Rosidah, dkk. (2020) menggunakan video edukasi, sedangkan Aulia (2020) memanfaatkan media sosial (WA, FB dan Instagram) dalam menampilkan poster edukasi terkait pencegahan Covid-19.

Warga yang bersedia menjadi mitra umumnya adalah ibu rumah tangga dan mahasiswa. Kedua tipe mitra ini sudah terbiasa menggunakan gawai meskipun menurut Novianti D. dan Fatonah S. (2018) kemampuan literasi media digital ibu rumah tangga berbeda. Namun demikian, menurut Yuliarso (2010), justru ibu-ibu rumah tangga memiliki peran sebagai narasumber nonformal sehingga informasi dapat tersampaikan ke tetangga dan teman dengan lebih nyaman, leluasa, tidak menimbulkan rasa rendah diri. Mitra lainnya berlatar profesi beragam, yaitu akuntan, tenaga administrasi, dokter gigi, tenaga pemasaran, pegawai foto copy, karyawan BUMN dan asisten rumah tangga. Mitra-mitra tersebut diharapkan dapat menjadi acuan, penerus informasi yang terdapat dalam buklet, sebagaimana pandangan Mardikanto (2015), yaitu "sebagian masyarakat yang masih tradisional akan lebih mempercayai pemimpin non formal, teman dan tetangga sebagai kelompok acuan dan sebagai sumber informasi dalam difusi inovasi”.

Lokasi tempat mitra berada berbedabeda sesuai tempat para mahasiswa bergerak melakukan KKN secara daring. Sebagian besar tinggal di wilayah Jawa Barat, yaitu Bandung, Kabupaten Bandung, Bekasi, Cirebon, Sumedang, Tasikmalaya,
Panyabungan, Purwakarta. Namun, ada juga yang berasal dari luar Jawa (Mandailing Natal dan Palangkaraya).

Hampir semua jawaban mitra menunjukkan bahwa mereka telah mengetahui perlunya melakukan protokol 3M (menjaga jarak, memakai masker, mencuci tangan). Akan tetapi, diakui bahwa protokol tidak sepenuhnya dilakukan pada saat tertentu. Ada 50\% mitra masih mencium tangan orang tua atau yang dituakan, $73 \%$ tidak duduk berjarak ketika bersama orang dekat (teman, kerabat) di ruang publik (cafe, rumah makan) dan $65,4 \%$ memilih duduk di dalam ruangan ber-AC.

Penyuluhan yang dilakukan merupakan kegiatan yang mengiringi peluncuran buklet digital. Kedua puluh mahasiswa bekerja dalam empat kelompok berbeda sesuai pokok bahasan tentang kesadaran warga terkait protokol kesehatan Covid-19. Setiap kelompok memaparkan hasil bahasan yang dituangkan di dalam buklet, sehingga ada empat pokok bahasan yang disampaikan, seperti tabel berikut ini.

Tabel 1. Pokok Bahasan dalam Buklet Digital

\begin{tabular}{ll}
\multicolumn{1}{c}{ Nama } & \multicolumn{1}{c}{ Bahasan } \\
\hline Kelompok I & Virus Covid-19 \\
Kelompok II & Protokol Kesehatan \\
& Gambaran Kepatuhan Warga \\
Kelompok III & tentang Protokol Kesehatan \\
Kelompok IV & Vaksin Covid-19 \\
\hline
\end{tabular}

Setelah pemaparan bahasan, langsung diperkenalkan buklet yang diberi judul COVID-101. Penggunaan angka 101 adalah untuk menarik perhatian pembaca. Angka 101 dapat dibaca one on one, yang menurut penjelasan kamus berbahasa Inggris adalah 'langsung antara dua individu'; 'dari orang ke orang'. One-o-one (101) menurut penjelasan situs internetslang.com juga 
berarti 'basic introduction', penjelasan dasar. Dengan demikian, penggunaan 101 pada judul adalah pilihan yang pas, karena sesuai dengan yang diusung oleh isi buklet serta fungsi buklet itu sendiri, yaitu: (1) dari satu orang untuk orang lain, dan (2) berisi 'penjelasan dasar'. Buklet edukatif tersebut dapat diakses melalui tautan https://drive.google.com/drive/folders/1CyQhaYj-mYaM7qV5uGaNVDJMK1eZ5i

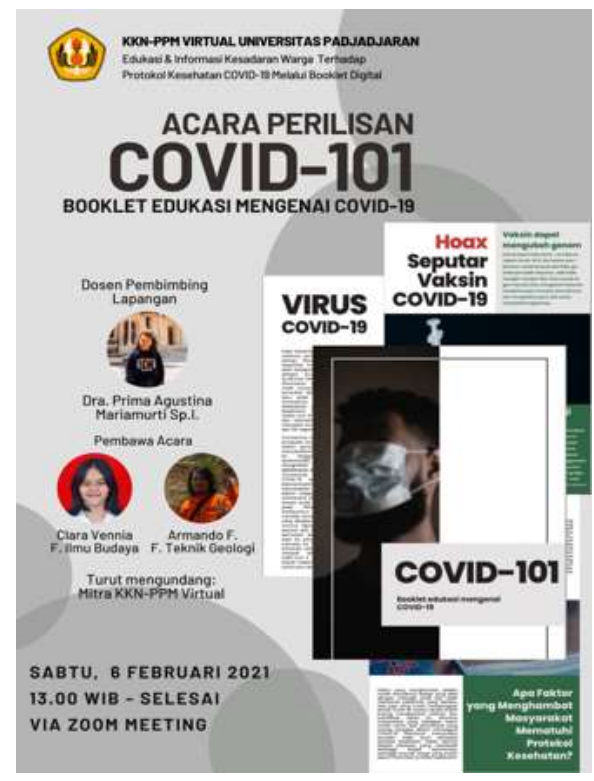

Gambar 1. Poster Kegiatan Peluncuran Buklet

Acara peluncuran buklet dan kegiatan antara mahasiswa dan mitra dalam membahas kesadaran warga mendapat apresiasi positif dari warga. Hal ini terlihat dari kesan dan pesan yang disampaikan dua orang mitra yang diundang berbicara dalam forum Zoom. Akbar Rofi dari Purwakarta menyatakan bahwa kegiatan yang dilakukan mahasiswa dan buklet sangat penting (skala 5 dari skala 5) dan menganggap bahwa kegiatan ini bermanfaat. Alamanda Nasution dari Palangkaraya pun memberikan angka 5 dari skala 5, artinya acara berdiskusi bersama mahasiswa KKN dan peluncuran buklet sangat penting dan diperlukan, bahkan ia menyarankan untuk meningkatkan acara semacam ini.

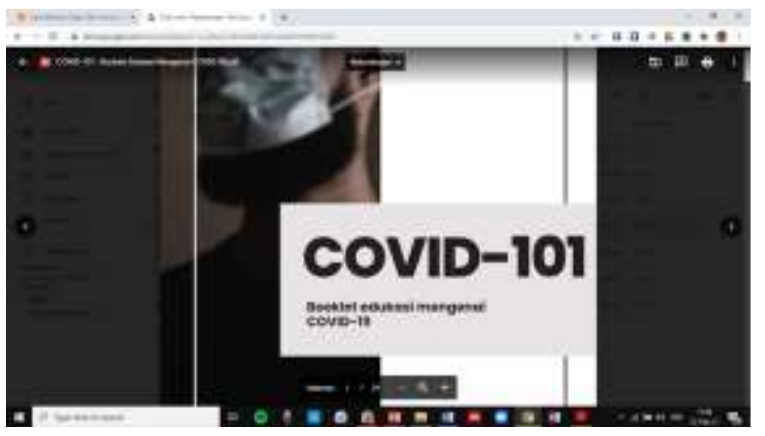

Gambar 2. Buklet Edukasi tentang Covid-19

Seperti yang dikemukakan Durkheim di akhir abad ke-19 terkait kesadaran kolektif, jika seluruh warga memiliki keyakinan yang sama untuk keluar dari suatu kondisi buruk, diharapkan tujuan bersama untuk mencapai kebaikan akan tercapai. Hal ini sama dengan yang disampaikan Mardikanto dan Soebiato (2015) tentang makhluk sosial, bahwa setiap individu akan selalu berperilaku sesuai dengan kondisi lingkungan sosialnya, atau setidak-tidaknya akan berusaha menyesuaikan diri dengan perilaku orang-orang di sekitarnya. Oleh karena itu, mitra yang baik dapat menjadi 'panutan' bagi warga lainnya.

Evaluasi yang diberikan dalam bentuk pertanyaan survei selepas acara selesai menunjukkan bahwa hampir semua menyukai kegiatan mahasiswa berupa penyuluhan dan peluncuran buklet edukasi ini. Artinya, kegiatan yang dilakukan bermanfaat dan tidak sia-sia karena warga semakin terbuka dan memahami apa itu virus Covid-19, dan vaksinasi. Warga menyadari perlunya mengikuti protokol kesehatan sebagai salah satu cara menghentikan penyebaran pandemi Covid-19 sehingga semua dapat kembali ke kondisi normal. 


\section{PENUTUP}

Kegiatan pengabdian pada masyarakat ini dilakukan untuk mengetahui sejauh mana warga memahami dan melaksanakan protokol kesehatan Covid-19. Masa pandemi menjadikan semua kegiatan dilaksanakan secara daring, virtual, tidak bertemu langsung dengan objek atau mitra. Namun, dari pembahasan yang dilakukan para mahasiswa KKN dengan warga yang menjadi mitra dan dari evaluasi yang dilakukan setelah acara peluncuran buklet selesai dilaksanakan dapat disimpulkan bahwa pada dasarnya warga telah memahami langkah dasar dalam memerangi virus Covid19 ini, yaitu melalui $3 \mathrm{M}$ (memakai masker, menjaga jarak, mencuci tangan).

Dari hasil evaluasi menyusul kegiatan peluncuran buklet dapat dikatakan bahwa warga menyambut baik kegiatan edukatif bersamaan dengan hadirnya buklet berjudul "Covid 101" yang bisa diakses melalui link internet. Penyuluhan sederhana, tanpa hadiah dan lainnya ini, memberi semangat dan manfaat bagi masyarakat. Melalui pikiran yang lebih terbuka tentang pandemi, virus dan vaksin, warga dapat menularkan wawasan dan informasi kepada siapa pun yang berada di lingkungan sekitar tempat tinggalnya.

Dari beberapa jawaban warga, kegiatan sosialisasi serupa masih diperlukan karena pandemi belum berakhir. Ada kekhawatiran bahwa orang-orang akan terlena dalam kondisi 'normal' yang berbeda ini.

\section{Ucapan Terima Kasih}

Tim PPM menyampaikan ucapan terima kasih dan penghargaan pada para mitra kegiatan dan mahasiswa Universitas Padjadjaran yang telah mendukung terselenggaranya kegiatan pengabdian kepada masyarakat ini.

\section{E. DAFTAR PUSTAKA}

Aulia, K. (2020). Meningkatkan Kesadaran Masyarakat Untuk Memperhatikan Prokes (Protokol Kesehatan) Dalam Beraktivitas Di Era Neno (new Normal) Dengan Media PEPC (poster Edukasi Pencegahan Covid-19) Melalui Media Wafagram (WA, Facebook, Dan Instagram) Di Kampung Padang Laban, Nagari Pasia Pelangai, Kecamatan Ranah Pesisir, Kabupaten Pesisir Selatan. OSF Preprints. doi:10.31219/osf.io/3upaj

Baudrillard, J. (1970). La société de consommation, ses mythes ses structures. Saint Amand: Editions Denoël.

Collective consciousness dalam https://sociologydictionary.org/collec tive-consciousness/

Cuffary, B. (2021). The Size of SARS-CoV2 Compared to Other Things

Keputusan Menteri Kesehatan Nomor HK.01.07/MENKES/382/2020, (2020).

Mardikanto, T. d. S., P. (2015). Pemberdayaan Masyarakat dalam Perspektif Kebijakan Publik. Bandung: Alfabeta.

Mardiyah, F. 2020. Apakah yang Dimaksud Protokol Kesehatan COVID19?dalam https://tirto.id/apakah-yangdimaksud-protokol-kesehatan-covid19-f3W3

Novianti, D. d. F., S. (2018). Literasi Media Digital di Lingkungan Ibu-Ibu Rumah Tangga di Yogyakarta. Jurnal Ilmu Komunikasi, 16(1), 1-14.

Protokol Tatalaksana COVID-19 di Indonesia (2021) dalam 
https://covid19.go.id/p/protokol/protok ol-tatalaksana-covid-19-di-indonesia

Rosidah, A., Khasanah, B., \& Kayyis, R. . (2020). Meningkatkan Kesadaran Masyarakat terhadap Pencegahan Covid-19 melalui Video Edukasi Penerapan Protokol Kesehatan. LOGISTA - Jurnal Ilmiah Pengabdian Kepada Masyarakat, 4(2), 414-419. doi:10.25077/logista.4.2.414-419.2020

What does 101 mean? - Meaning of 101 dalam https://www.internetslang.com > 101-meaning-definition

Yuliarso, M. Z. (2010). Perilaku Komunikasi Ibu Rumah Tangga. Jurnal Agrisep, 9(2), 175-183. 